\title{
Comparing methods for measuring crime harm/severity
}

\author{
Matt Ashby
}

June 2017

\section{PRE PRINT}

This is a pre-print of an article submitted to a journal, and has not yet been peer reviewed. Please send any questions or comments to matthew.ashby@ntu.ac.uk

\begin{abstract}
Ensuring police resources are focused where they are most needed requires understanding of the consequences of crime in relation to offenders, victims and places. Most crime analysis is based on counts of crimes, but not all crimes are equivalent to one another. Researchers have recently developed two methods - the Crime Harm Index and the Crime Severity Score - for weighting crime counts according to the severity of different crime types. This article compares these two methods by applying them to two common crimeanalysis scenarios: focusing resources on the most-important types of crime and in the areas most affected by crime. The two measures are found to produce substantially different results when other factors are held constant. The results of severity-weighted crime analysis (and the decision made based on them) could therefore be greatly influenced by the method chosen. The implications of this are discussed and future research avenues outlined.
\end{abstract}

\section{Introduction}

This article compares two methods that have recently been proposed for weighting counts of crime in England and Wales according to the seriousness of different offences, so as to give greater priority to those offences that cause the most damage to individuals or society. These methods are the Cambridge Crime Harm Index and the Office for National 
Statistics Crime Severity Score.

These methods have the same objective but differ in the basis on which they estimate the relative seriousness of different crimes. This article will demonstrate that these different approaches produce substantial differences in the estimates made, both in comparing types of crime to one another and in comparing the total seriousness of crime in different areas. It will also give examples of how these differences could lead to researchers and practitioners reaching different conclusions based solely on their choice of one method rather than the other.

\section{Why estimate the overall seriousness of crime?}

The past decade has been a time of substantial change for policing in England and Wales. Pressure on public-sector budgets caused by government responses to the 2008 financial crisis has led to substantial resource reductions, with the number of police officers in England and Wales per head of population in 2016 being the lowest since 1974 (Figure 1). At the same time, a system in which many policing priorities were set nationally has been replaced by one in which an elected Police and Crime Commissioner (PCC) in each force sets most priorities locally (Hales and Higgins 2016). National targets to reduce particular types of crime have been abandoned, replaced by local priorities that differ across forces. Finally, reports into policing failures such as the Rotherham child-abuse scandal (Jay 2014) and the death of Fiona Pilkington (Independent Police Complaints Commission 2011) provided reminders that policing responsibilities are (and always have been) much broader than dealing with the types of volume crime (most notably residential burglary, car theft and street robbery) that consumed much of the attention of policy makers in the 1990s and early 2000s.

Combined, these factors have meant that police forces are now responsible for deciding how to allocate their dwindling resources across an array of problems that is at least as wide as it has been in the past. The question of which problems get which resources is a difficult one, with many potential answers (see, for example, Higgins 2017, in the context of neighbourhood policing).

One method of allocating scarce resources has been to try to focus resources on those 
Figure 1: Number of police officers per capita in England and Wales, 1966-2017.

Data: Home Office (2017a)

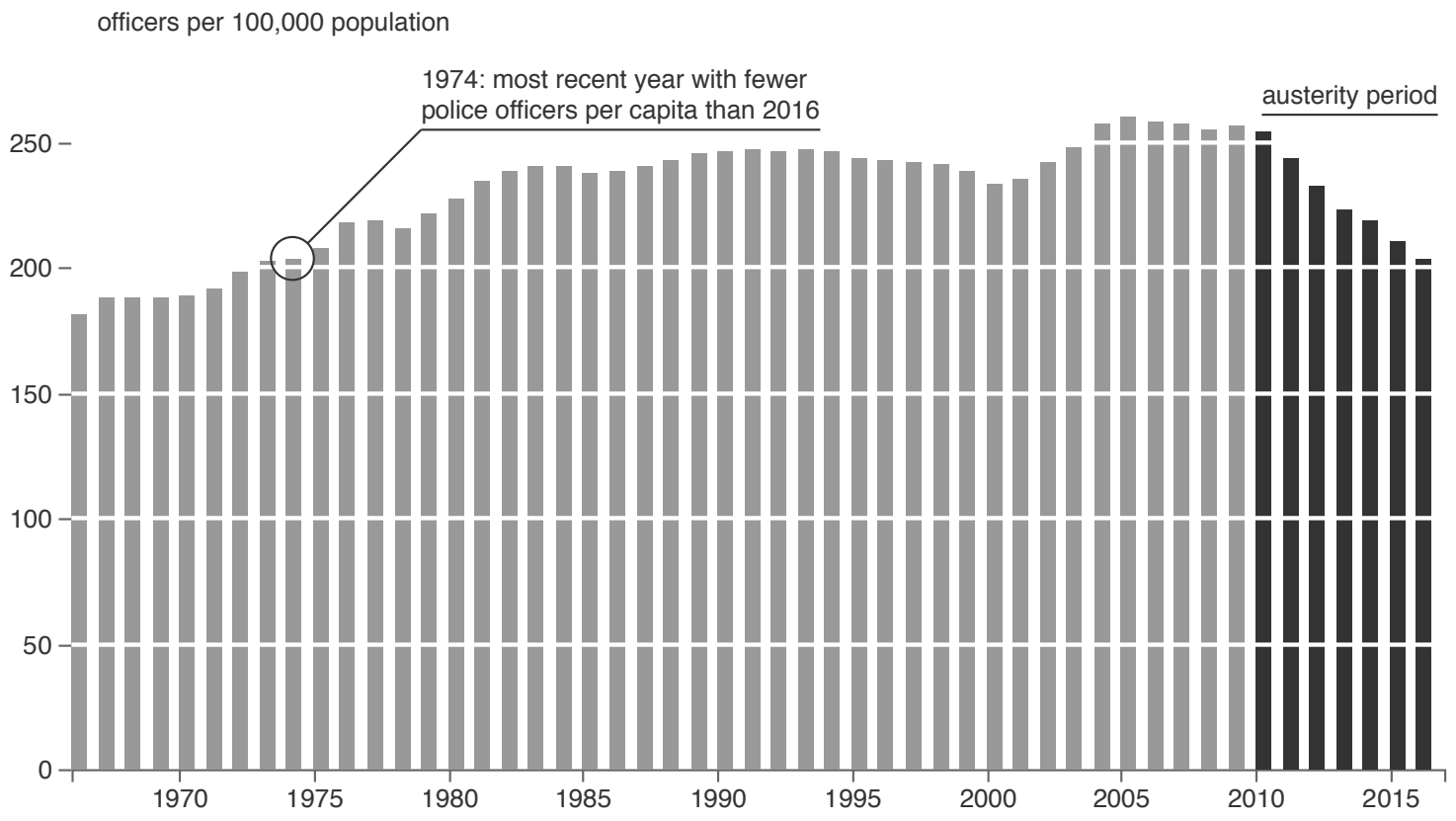

problems that cause the most harm to communities. For example, the national strategy for roads policing emphasises "focused harm reduction" by targeting "those high harm offenders who pose the greatest risks to the safety of others" (Association of Chief Police Officers 2010, pp 1-2). The 'Policing Vision 2025', jointly published in 2016 by the Association of Police and Crime Commissioners (APCC) and National Police Chiefs' Council (NPCC), commits the police to focusing on "high harm" offences (p 6).

This renewed focus on reducing harm fits well with the increasing interest in evidencebased policing (EBP). Sherman (2013) described focusing police resources on the victims, offenders and places that most need them as one of the the three fundamental practices of EBP. He referred to focusing resources as "targeting", a term that has unfortunate connotations in British policing because setting numerical performance targets for volume crime is widely seen as having hampered a focus on less-visible offences that can cause the most harm (Guilfoyle 2012). Whatever terms are used, there is strong evidence that it is effective to focus police resources on prolific offenders (e.g. Sherman and Eck 2002), repeat victims (e.g. Grove et al. 2012) and places at which crimes frequently happen (e.g. Braga et al. 2014). 


\section{Methods for estimating crime harm}

It is without doubt that some types of criminal activity cause more harm than others: it is a crime to murder and it is a crime to shoplift, but those two crimes are vastly different in the harm that they cause to the victim and to society. However, to understand the harms caused by different crimes it is necessary to have more-detailed information than the bald statement that shoplifting is less serious than murder.

Identifying the true harms caused by crime is difficult because harm can come in so many forms. There are enormous, and hugely varying, financial costs of crime, both for the victim and for society (McCollister et al. 2010). Many crimes cause serious emotional harm to victims (Frieze et al. 1987), which is likely to be different for different people even within a single crime type (Kilpatrick et al. 1989). Crime can also cause environmental and social harm (Bricknell 2010).

The different types of harm caused by crime mean that overall harm can be estimated in several ways. For any estimation method to be valuable for policing purposes, it must fulfil at least four criteria: comparability, consistency, transparency and affordability.

Comparability means different crimes must be made comparable to one another, since prioritising resources means some be given greater attention than others. This is difficult because one crime type may, for example, be more financially harmful than another type but less socially harmful.

Consistency means any estimate must be reproducible, to allow comparison of estimates produced by different analysts in different areas. This precludes estimates based on individual perceptions of harm, although such estimates may be useful for other purposes (Ignatans and Pease 2015).

Transparency means it must be possible to understand how an estimate of crime harm is produced. This ensures decision makers know the limitations of that method, and allows people affected by decisions made on the basis of such estimates to hold decision makers to account.

Finally, affordability means it must be possible to deploy a method without diverting scarce police or other public-sector resources. This, for example, precludes methods that require extensive collection of data that are not collected for an existing policing purpose. 
There have been several attempts to develop indices of crime harm (for a recent review, see Sherman et al. 2016b). Sellin and Wolfgang developed an index based on perceptions of harm derived from a population survey in the United States as long ago as 1964, an effort later updated by Wolfgang et al. (1985). However, similar work in the United Kingdom has been limited.

That position has changed recently, with the development of two methods that appear to fulfil the criteria set out above. The Cambridge Crime Harm Index (CHI) developed by Sherman et al. (2016b) uses sentencing guidelines issued to judges and magistrates as a proxy for the typical harm caused by each type of crime. The Crime Severity Score (CSS) developed by the Office for National Statistics (2016b) takes a slightly different approach, using the mean sentence actually passed on those convicted of offences in each type rather than the guideline sentence.

One difference between these two measures is terminology: the CHI refers to crime 'harm' while the CSS discusses the 'severity' of crime. In their explanation of the CHI, Sherman et al. (2016b) appeared to treat harm as being synonymous with seriousness, although they did not explicitly discuss it. Since the focus of this article is to compare the two measures, rather than to critique the general concept of producing weighted counts of crimes (for which, see Maguire and McVie 2017), the words harm and severity will be used interchangeably in the discussion that follows.

The CHI is based on the perceptions of crime severity expressed by the Sentencing Council for England and Wales in the guidelines that they issue to magistrates and judges (Sherman et al. 2016b)1. The logic behind this is that the severity of a particular offence is "the key factor" (emphasis added) in deciding on the level of any custodial, community or financial penalty imposed by a court (Sentencing Guidelines Council 2004, p 3). As such, the severity of any sentence set out in a guideline is deemed to be proportionate to the overall severity of the offence, taking into account the different types of harm that crime causes (Sherman et al. 2016b).

Sentencing guidelines provide a range of possible sentences, to allow judges or magistrates to account for the individual circumstances of each offence. Guidelines there-

\footnotetext{
${ }^{1}$ Until 2010, the Sentencing Council for England and Wales was known as the Sentencing Guidelines Council.
} 
fore usually include a starting-point sentence, followed by a list of potential aggravating and mitigating factors that might justify increasing or decreasing the sentence relative to the starting point. Potential aggravating factors include racial hostility towards the victim, while mitigating factors include extensive provocation (Sentencing Guidelines Council 2008). The CHI is based on the starting-point sentence that would be given to an adult offender with no previous convictions in a case with no aggravating or mitigating factors, expressed in terms of days of imprisonment (Sherman et al. 2016b).

The CSS is derived by calculating the mean number of days imprisonment that offenders were sentenced to serve after conviction for each type of offence in the five years ending in December 2015 (Office for National Statistics 2016b). Both methods convert non-custodial sentences into nominal days of imprisonment using a similar method, as outlined in Office for National Statistics (2016b) and Sherman et al. (2016b).

If all offenders were given the starting-point sentence, the two measures would be equivalent. However, there are several reasons why actual sentences may deviate from the relevant guideline. Firstly, some offences may be more-commonly associated with aggravating factors than other offences. For example, car thieves are particularly likely to reoffend after release (Langan and Levin 2002, p 8), which would be an aggravating factor when they are sentenced for subsequent offences.

Some offences are disproportionately dealt with by out-of-court disposals, which may mean that those cases which go to court (and so contribute to sentencing statistics) are more serious than a typical offence in that category. For example, in the year ending September 2015 more than 12,000 shoplifting offences were dealt with by issuing a fixed penalty notice (Ministry of Justice 2016), meaning the offender did not enter the sentencing system. Since fixed penalties can only be issued for minor shoplifting offences (Ministry of Justice 2014), offences dealt with by the courts may be unusually serious. If so, this could distort the mean sentence for shoplifting relative to the sentencing guideline.

In England and Wales, offenders who plead guilty at the "first reasonable opportunity" are entitled to a one-third discount on their sentence, with a reduced discount being available for later guilty pleas (Sentencing Guidelines Council 2007). Since offenders appear less likely to plead guilty for some offences (Feist et al.2007), this may lead to such offences being over-weighted in the CSS if a greater proportion of sentences for those offences do 
not include a discount for a guilty plea.

For these reasons, it is likely that there will be differences between the estimates of crime severity produced by the CHI and CSS. The question this article seeks to answer is: are these differences likely to have any material impact on the results of analysis that uses one of these measures to estimate the severity of crime?

\section{Comparing CHI and CSS values for individual offences}

The previous section outlined several theoretical reasons why severity estimates produced by the CHI and CSS might differ from one another. This section explains what differences actually exist in practice. To quantify the differences for individual offences, it was necessary to calculate the value for each offence type. CSS values were obtained from Office for National Statistics (2016b), while CHI values were kindly provided by the team that developed that index.

The CSS and CHI values were not immediately comparable because they categorised crimes in different ways. The CSS provides severity scores for each offence on the Home Office Notifiable Offences List (NOL) (Home Office 2011, pp 56-61), with a small number of very-rare offences such as infanticide being collapsed into related categories (for a full list, see Appendix A. CHI values, however, have been generated for a selection of Home Office statistics codes, which provide a more-detailed classification than the NOL. For example, murder is a single category within the NOL but includes offences with two different Home Office codes, one for murder of a person aged one year or over, and one for victims aged under one year.

Some Home Office codes are extremely obscure, such as code 195/39 which represents the offence of indecent behaviour in a church or chapel, contrary to section 2 of the Ecclesiastical Courts Jurisdiction Act of 1860. The list of CHI weights does not generally cover such offences. A further issue is that some offences, particularly those newly enacted, are not covered by any sentencing guidelines.

To compare the two measures of severity, it was necessary to aggregate the Home Office codes used for the CHI to the NOL categories used by the CSS. In most cases a single sentencing guideline covered all Home Office codes within a NOL category. For example, 
the two Home Office codes making up category 19C (rape of a female aged 16 or over) carry the same starting-point sentence of five years' imprisonment. However, in some cases the offences within an NOL category carry vastly different guideline sentences. For example, NOL category 17A (sexual assault on a male aged 13 or over) includes the offences of sexual assault on a male (Home Office code 017/15) with a starting point of a high-level community order, and sexual assault on a male by penetration (Home Office code 017/13) with a stating point of two years' imprisonment. In these cases, the lower starting point was applied on the basis that less-serious offences are usually more common.

Figure 2 compares the CHI and CSS values for each of 120 NOL categories. Four categories could not be included because there is no sentencing guideline on which to base the CHI value 2 , but together these represent less than $0.1 \%$ of all offences recorded by police.

Each NOL category in Figure 2 is represented by a circle, scaled proportionally to the number of offences in that category recorded by police in England and Wales in the 12 months ending in March 2016, published in Home Office (2017b). A complete list of NOL codes, CHI and CSS values is given at Appendix A.

For most offence categories, the CSS value is greater than the CHI value: mean sentences are typically longer than the starting-point guideline sentence for that offence. In many cases this difference is substantial. For example, the starting-point guideline sentence (CHI value) for assaults with injury (NOL category $8 \mathrm{~N}$ ) is 19 days imprisonment, but the actual mean sentence (CSS value) is 184 days - almost ten-times greater. At the extreme, the CSS value for possession of false documents (NOL category 61A) is 66-times greater than the CHI value for that category. This may be because aggravating factors are typically more numerous or more severe than mitigating factors in sentencing for many offences, as discussed in the previous section.

There are, however, exceptions: the guideline sentence for intentional destruction of a viable unborn child (NOL category 4.3) is 365 days imprisonment but the mean actual sentence is 15 days imprisonment. These atypical cases may be the result of such offences being more likely to feature mitigating factors relating, for example, to the offender's state

\footnotetext{
${ }^{2}$ These were NOL categories 14 (procuring an illegal abortion), 55 (bankruptcy offences), 90 (other knives offences) and 99 (other notifiable offences)
} 
Figure 2: Offence severity weights generated by the CHI and CSS. Both axes have logarithmic scales. Categories with more than 100,000 crimes, or for which the weight given by one method is more than 50 times different from the weight given by the other method, are labelled; see Appendix A for a full list.

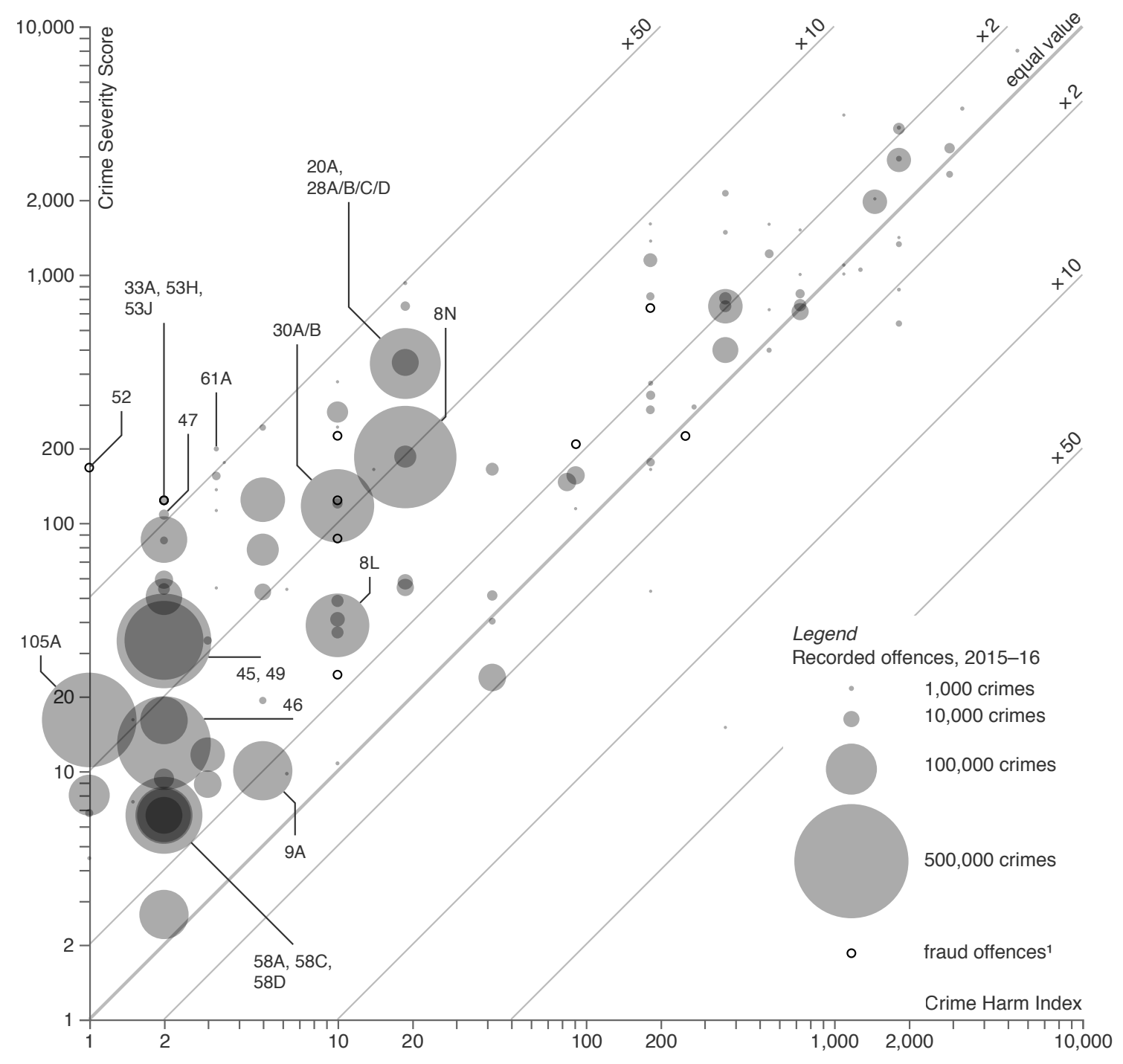

1 offence counts for Notifiable Offence List categories related to fraud are no longer published by the Home Office 
of mind (for a discussion of such issues in relation to child destruction, see Shelton et al. 2011).

\section{What impact might this have in practice?}

Figure 2 shows that there are substantial differences between the harm/severity weightings generated by the CHI and CSS. However, it remains to be seen whether these differences have any impact on any potential uses of the CHI or CSS in practice.

One suggested use of the two indices is in allocating resources to areas where the harm caused by crime is greatest (Huey 2016; Sherman et al. 2016b). There are multiple aspects to resource allocation, one of which is the prioritisation of types of crime. Figure 3 shows the CHI and CSS estimates of the proportion of total crime harm/severity in England and Wales caused by each of the 23 Home Office offence subgroups.

Figure 3 is a parallel co-ordinate plot (Inselberg 1997), in which the position of each dot on the vertical axes represents the proportion of harm caused by each category according to each method, while the difference between the two methods for each category is shown by the line connecting each pair of dots (one for each method). The ten categories causing the most harm according to each measure are labelled.

If the two methods produced the same estimates, all the lines in Figure 3 would be horizontal. That some lines a sharply sloped shows that there are substantial differences between the two measures in those categories. For example, rape accounts for over one third of all crime harm according to the CHI, but only about one fifth according to the CSS. Conversely, domestic burglary represents $16.1 \%$ of harm according to the CSS, but only $2.1 \%$ according to the CHI. That some lines cross one another shows that there are also differences in the ordering of crime types. For example, the CHI estimates trafficking of drugs to cause greater harm than violence without injury, while the opposite is true according to the CSS.

These very large differences are caused entirely by the different methods used by the CHI and CSS. If a measure of harm/severity were to be used to allocate scarce policing or crime-prevention resources, the choice of measure would substantially influence the results.

Another aspect of resource allocation is the division of resources between geographic 
Figure 3: Estimated proportion of total crime severity attributable to each of the Home Office offence subgroups, as measured by the CHI and CSS, based on police-recorded crime in England and Wales in 2015-16.

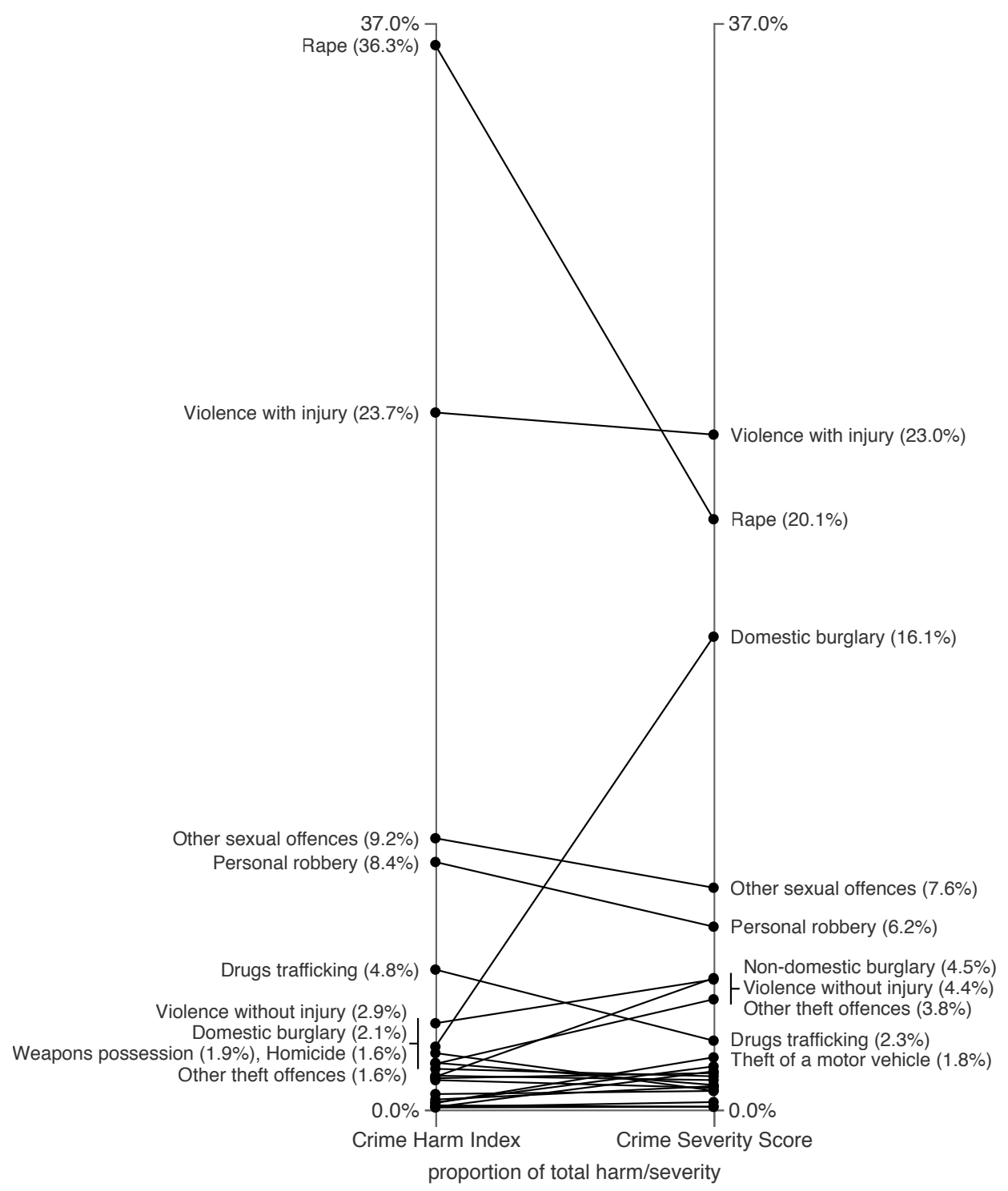


Figure 4: Estimated crime harm/severity per 1,000 residents as measured by the CHI and CSS, excluding City of London Police, based on police-recorded crime in England and Wales in $2015-16$.

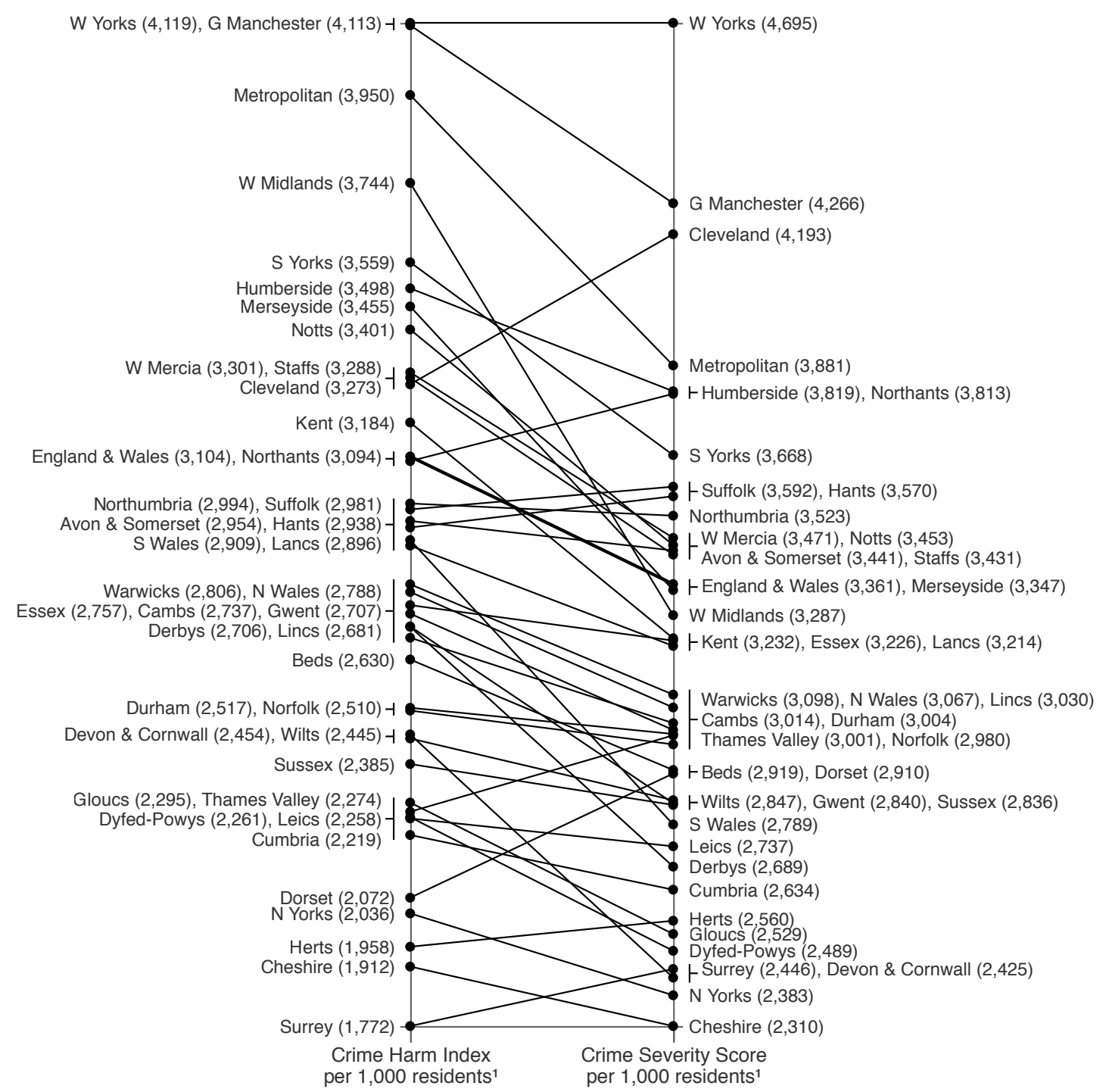

1 excludes fraud, since offence counts for NOL categories related to fraud are no longer published by the Home Office 
areas. Figure 4 compares the CHI and CSS estimated rate of harm/severity per 1,000 residents in each police force area in England and Wales.

Once again, there are substantial differences in both the values produced by the two estimation methods and in the ordering of forces. For example, the rate of harm per 1,000 residents estimated by the CSS in the Cleveland Police area is $50 \%$ greater than that estimated by the CHI. Conversely, the West Midlands Police area has the third highest rate of harm according to the $\mathrm{CHI}$ but only the 17th highest rate according to the CSS. If resources were to be allocated to forces according to the relative severity of crime in each area, the allocation of resources would appear to depend heavily on the estimation method chosen.

This can be seen using the example of government funding for the police. Forces in England and Wales are funded partly through local taxation and partly from a central government grant (Johnson and Politowski 2016). The amount of grant money received by each force is determined by a formula that is designed to reflect the challenges facing police in each area. The present formula attempts to capture the demand caused by crime in each area by measuring correlates of crime such as unemployment and population density (Home Office 2015), but has been criticised as "outdated, vague and unfair" (Ludwig and McLean 2016, p 2). If a new formula were to incorporate a measure of crime harm or severity (as suggested by Sherman et al. 2016b), what effect would the choice of measure have on the funding allocated to each force?

Imagine the hypothetical case of $25 \%$ of central government funding to a police force being allocated based on the proportion of total crime harm dealt with by that force. Figure 5 shows the difference between the funding each force would get in such a scenario if harm were estimated according to the CHI or CSS, expressed as a percentage of each force's government grant for the 2015-16 year. The right-hand column shows this difference in absolute terms.

The difference between annual allocations using the two methods would be greater than $£ 1$ million for 33 of the 43 forces in England and Wales. Based on the NPCC estimate of the cost of a police officer (including direct overheads) of $£ 56,134$ per year (National Police Chiefs' Council 2015), this difference could have a substantial impact on the number of officers a force can afford to deploy. For example, the difference is greater than 
Figure 5: Difference in police funding if $25 \%$ of the central-government grant to forces were allocated according to the CHI or CSS, as a percentage of current funding, based on police-recorded crime in $2015-16$.

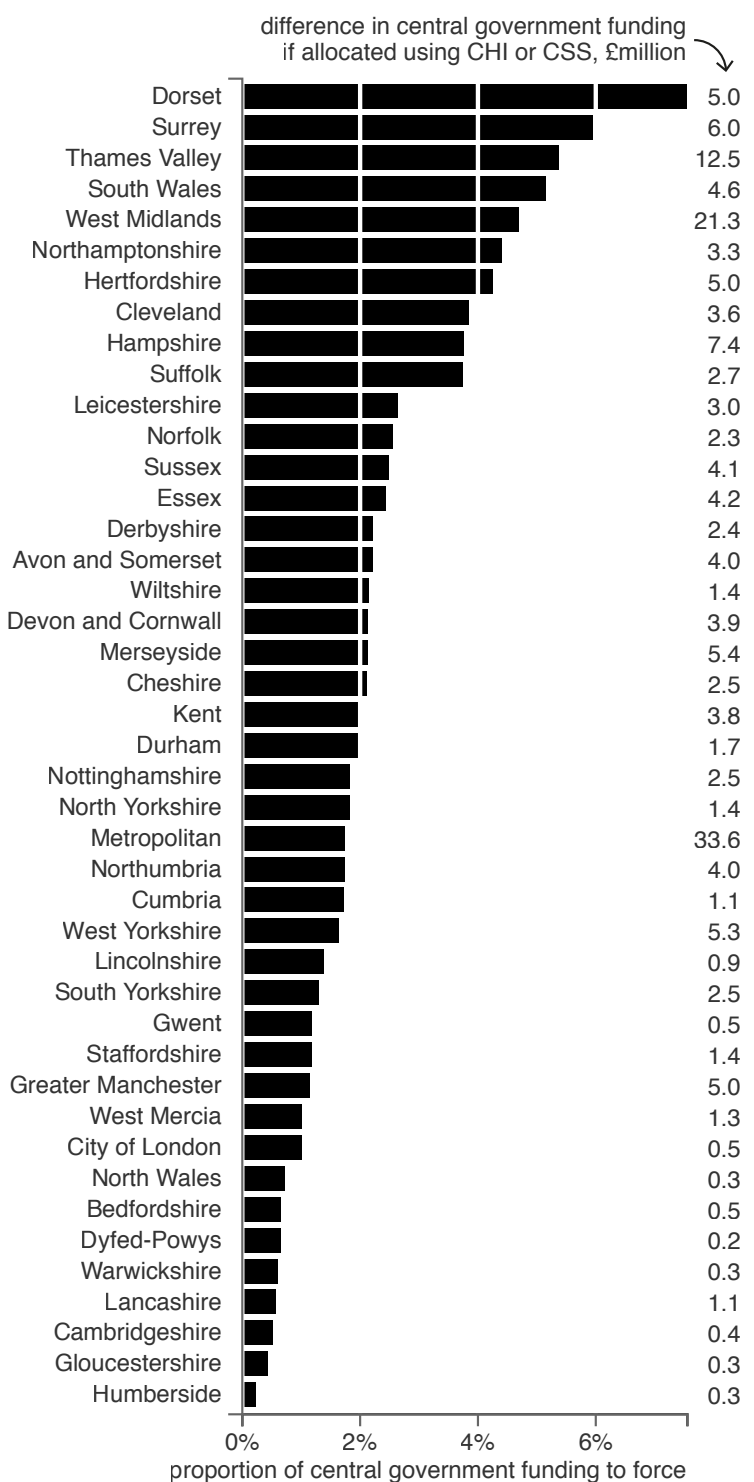


100 officers for the Hampshire, Metropolitan, Surrey, Thames Valley and West Midlands forces. However, small forces would also experience substantial differences according to the method used: for Dorset Police, the difference would be equivalent to $7.5 \%$ of the annual government grant.

Overall, it can be seen that choice of estimation method can have a substantial impact on the apparent severity of crime in an area, even when all other factors are held constant. Estimates of harm produced using the CHI and CSS are not comparable to one another, and the two should not be used interchangeably. Given these differences, the next section of this article discusses which of the two methods researchers and practitioners should use.

\section{Which method to use?}

The benefits of estimating weighted counts of crime, outlined by Sherman et al. (2016b) among others, are clear. The resources available to prevent and respond to crime will always be limited and so must be directed where they are needed most. Prioritising resources requires a means of determining which people and places are most affected by crime, and this is better done by using a harm-weighted count of crimes than by a simple tally.

This does not mean that either the CHI or CSS is perfect. Both assume that every crime in a particular category has the same degree of seriousness. This is clearly not true: some burglaries (for example) involve violence, extensive damage to property or the theft of items of sentimental value, while others have none of those features. Even if two offences of the same type are identical, different victims may experience them in very different ways.

Nevertheless, it is clear that weighting crime counts by severity has potential benefits both for research and practice. This can be seen in their rapid adoption both within policing and academia (see, for example, Ashby 2017; Bland and Ariel 2015; Dudfield et al. 2017, Sherman et al. 2016a). Since two measures are available, the question arises of which is more useful.

The CHI and CSS have different weaknesses. Since it is based on actual sentences, the CSS reflects sentencing considerations that are unrelated to offence severity. For example, in 2016 the most senior judge in England and Wales recommended greater use of noncustodial sentences to tackle prison overcrowding (Hughes 2016), which could influence 
sentencing without any change in offence severity. Some offences are disproportionately committed by persistent offenders - Moore (1984) found two-thirds of convicted shoplifters offended at least weekly - which will inflate the mean sentence for such crimes.

Sherman et al. (2016b) argued against the use of indices (such as the CSS) based on actual sentences precisely because they are influenced by factors other than severity. However, such indices may also capture elements of severity that are ignored by methods (such as the CHI) based on sentencing guidelines. If a particular offence almost-always involves substantial mitigation - such as child destruction, discussed above - then a sentencing guideline may systematically overstate the severity of such offences. Conversely, if an offence very-often has aggravating features - such as distraction burglaries, which almost always target vulnerable victims (Lister et al. 2004) - severity may be systematically under-estimated. In such cases, an index based on actual sentences may better reflect the severity of crime.

Given that both measures have the potential to produce biased estimates of crime harm (although both appear to be better than unweighted counts of crime), there does not appear to be any reason to prefer one measure over the other. However, since the two methods produce substantially different estimates, it would be beneficial for a consensus to emerge among academics and professionals as to which method is used. This would allow the work of different groups to be compared, and allow researchers to build on the work of others.

Both the CHI and CSS could be improved to make them easier to use and to provide more useful information. At present, the CHI does not cover all offences because there are crimes for which there are no sentencing guidelines. The Sentencing Council is developing guidelines for such offences, but this is a lengthy process (Sentencing Council 2016). It may be valuable to develop ways to incorporate offences without guidelines into the CHI as an interim solution.

The CSS covers all offence types, but only at the relatively aggregate level of the NOL categories. As described above, some of these categories contain offences of substantially different severity, and the category of other notifiable offences covers a wide range of offending.

This is likely to be particularly problematic in uses of a severity index that require 
differentiation of similar offences. For example, it would be difficult for a police force to prioritise drug investigations based on harm/severity, because all drug trafficking offences are covered by a single NOL category (92A).

Publishing CSS estimates for more-granular offence types would potentially be problematic because very few offenders would be sentenced in some categories. This would mean that the CSS estimates for such offences would be based on a very small sample size. Even at the current level of aggregation, there are five NOL categories with fewer than 10 cases recorded in 2015-16 (see Appendix A). Nevertheless, some NOL types cover very many offences: more than 400,000 offences were recorded in the largest category, assault with injury $(8 \mathrm{~N})$, in $2015-16$.

The best level of aggregation at which to strike the balance between sufficient detail and acceptable sample size may be the list of Home Office statistics codes referred to earlier. In the case of drug trafficking, the single NOL code is broken down into separate statistics codes for each of the common drugs encountered in the United Kingdom. This would provide useful additional information for some uses of severity weighting, and the Office for National Statistics (ONS) should consider producing CSS estimates at this level of detail.

Sherman et al. (2016b, p 8) describe the current CHI as a "beta" version to be enhanced further, while the Office for National Statistics (2016b) have requested feedback on the CSS. It may be that as these measures develop, one proves to be more useful than the other or is subject to greater development. In such circumstances, there may be grounds for preferring one over the other.

\section{Conclusion}

This article has demonstrated that there are substantial differences between the estimates of crime harm/severity produced by the CHI and CSS. These differences have the potential to be a major influence on the conclusions drawn from analysis based on such indices, and so analysts should exercise caution in their choice of index and their interpretation of results based on it.

Whichever measure becomes most widely used, further research is necessary to under- 
stand how effective these measures are as crime analysis tools. In keeping with the focus of EBP on targeting resources where they are most needed, such research could usefully focus on applying the CHI or CSS to concentrations of crime among offenders, victims and places. Which offenders cause the most harm? Which victims suffer the most harm? And in which places does the most harm occur? It would also be useful to compare both indices to public perceptions of the severity of crime, to ensure that harm-focused policing enjoys public legitimacy. Finally, one limitation of both methods at present is that they do not capture the harm caused by crime that is not reported to police - adjusting harm/severity estimates to account for reporting rates would be a potentially useful addition to both the CHI and CSS.

It appears that analysis using weighted counts is being received favourably by several police forces, so it may be that some of these research questions are already being addressed by police analysts. If that is the case, it is important that the results of such work are disseminated (for example in journals such as this) so that practitioners and researchers elsewhere can benefit from the insights produced.

\section{Acknowledgements}

The author wishes to thank Mark Bangs of the Office for National Statistics and Eleanor Neyroud of the University of Cambridge for their helpful comments on aspects of this research. 


\section{References}

Ashby, M P J (2017). 'The Value of CCTV Surveillance Cameras as an Investigative Tool: An Empirical Analysis'. In: European Journal on Criminal Policy and Research. DOI: 10.1007/s10610-017-9341-6.

Association of Chief Police Officers (2010). Policing the Roads - 5 Year Strategy 2011-2015. Wymondham, Norfolk: Association of Chief Police Officers.

Association of Police and Crime Commissioners and National Police Chiefs' Council (2016). Policing Vision 2025. London: National Police Chiefs' Council.

Bland, M and B Ariel (2015). 'Targeting Escalation in Reported Domestic Abuse Evidence from 36,000 Callouts'. In: International Criminal Justice Review 25.1, pp. 30-53.

Braga, A, A Papachristos and D Hureau (2014). 'The effects of hot spots policing on crime: an updated systematic review and meta-analysis'. In: Justice Quarterly 31.4, pp. 633-663. DOI: 10.4073/csr.2012.8.

Bricknell, S (2010). Environmental crime in Australia. Research and Public Policy Series 109. Canberra: Australian Institute of Criminology.

Dudfield, G, C Angel, L W Sherman and S Torrence (2017). 'The "Power Curve" of Victim Harm: Targeting the Distribution of Crime Harm Index Values Across All Victims and Repeat Victims over 1 Year'. In: Cambridge Journal of Evidence-Based Policing. DOI: $10.1007 / \mathrm{s} 41887-017-0001-3$.

Feist, A, J Ashe, J Lawrence, D McPhee and R Wilson (2007). Investigating and Detecting Recorded Offences of Rape. London: Home Office.

Frieze, I H, S Hymer and M S Greenberg (1987). 'Describing the crime victim: psychological reactions to victimization'. In: Professional Psychology: Research and Practice 18.4, pp. 299-315. DOI: 10.1037/0735-7028.18.4.299.

Grove, L E, G Farrell, D P Farrington and S D Johnson (2012). Preventing repeat victimization: a systematic review. Stockholm: Swedish National Council for Crime Prevention.

Guilfoyle, S. (2012). 'On target?-Public sector performance management: recurrent themes, consequences and questions'. In: Policing 6.3, pp. 250-260. DOI: $10.1093 /$ police/pas001.

Hales, G and A Higgins (2016). Prioritisation in a changing world: seven challenges for policing. London: Police Foundation.

Higgins, A (2017). Neighbourhood policing: a police force typology. London: Police Foundation.

Home Office (2011). User Guide to Home Office Crime Statistics. London: Home Office.

- (2015). The Police Grant Report (England and Wales) 2015/16. London: Home Office.

- (2017a). Historical numbers of police officers. URL: https: //www.whatdotheyknow.com/request/historical_numbers_of_police_off

- (2017b). Police recorded crime and outcomes open data tables. URL: https://www.gov.uk/government/statistics/police-recorded-crime-opendata-tables.

Huey, L (2016). 'Harm-focused policing'. In: Journal of Community Safety and Well-being 1.3, pp. 83-85.

Hughes, L (2016). 'More criminals should be given community sentences instead of being jailed, says Britain's most senior judge'. In: The Telegraph. URL: 
http://www.telegraph.co.uk/news/2016/11/22/criminals-should-givencommunity-sentences-instead-jailed-saysbritains/.

Ignatans, D and K Pease (2015). 'Taking crime seriously: playing the weighting game'.

In: Policing 10.3, pp. 184-193. DOI: 10.1093/police/pav029.

Independent Police Complaints Commission (2011). IPCC report into the contact between

Fiona Pilkington and Leicestershire Constabulary 2004-200\%. London: Independent

Police Complaints Commission. URL: https://www.ipcc.gov.uk/news/ipcc-

publishes-fiona-pilkington-investigation-report.

Inselberg, A. (1997). 'Multidimensional detective'. In: Proceedings of VIZ '97:

Visualization Conference, Information Visualization Symposium and Parallel

Rendering Symposium. Phoenix: IEEE, pp. 100-107. DOI:

10.1109/INFVIS.1997.636793.

Jay, A (2014). Independent Inquiry into Child Sexual Exploitation in Rotherham, 1997-2003. Rotherham: Rotherham Metropolitan Borough Council.

Johnson, N and B Politowski (2016). Police Funding. Briefing Paper series 7279. London: House of Commons Library.

Kilpatrick, D G, B E Saunders, A Amick-McMullan, C L Best, L J Veronen and H S Resnick (1989). 'Victim and crime factors associated with the development of crime-related post-traumatic stress disorder'. In: Behavior Therapy 20.2,

pp. 199-214. DOI: 10.1016/S0005-7894(89)80069-3.

Langan, P and D J Levin (2002). Recidivism of Prisoners Released in 1994. Washington, DC: US Department of Justice.

Lister, S, D Wall and J Bryan (2004). Evaluation of the Leeds Distraction Burglary Initiative. Home Office Online Report series 44/04. London: Home Office.

Ludwig, A and I McLean (2016). Principles of Police Funding in the UK. Gwilym Gibbon Centre Working Papers series. Oxford: Nuffield College.

Maguire, M and S McVie (2017). 'Crime data and criminal statistics: a critical reflection'. In: Oxford Handbook of Criminology. Ed. by A Liebling, S Maruna and L McAra. 6th ed. Oxford: Oxford University Press. Chap. 7, pp. 163-189.

McCollister, K E, M T French and H Fang (2010). 'The cost of crime to society: new crime-specific estimates for policy and program evaluation'. In: Drug and Alcohol Dependence 108.1-2, pp. 98-109. DOI: 10.1016/j.drugalcdep.2009.12.002.

Ministry of Justice (2014). Penalty Notices for Disorder: guidance for police officers. London: Ministry of Justice. URL: https://www.gov.uk/government/publications/penalty-notices-fordisorder-guidance-for-police-officers

- (2016). Criminal Justice System statistics quarterly: September 2016. URL: https://www.gov.uk/government/statistics/criminal-justice-systemstatistics-quarterly-september-2016.

Moore, R H (1984). 'Shoplifting in Middle America: Patterns and Motivational Correlates'. In: International Journal of Offender Therapy and Comparative Criminology 28.1, pp. 53-64.

National Police Chiefs' Council (2015). National Policing Guidelines on Charging for Police Services. London: National Police Chiefs' Council.

Office for National Statistics (2016a). Crime Severity Score data tool. URL: https://www.ons.gov.uk/peoplepopulationandcommunity/crimeandjustice/ datasets/crimeseverityscoredatatool.

- (2016b). Research outputs: developing a Crime Severity Score for England and Wales using data on crimes recorded by the police. URL: http://bit.ly/2fZCUbY. 
Sellin, T and M E Wolfgang (1964). The Measurement of Delinquency. New York: Wiley. Sentencing Council (2016). Business Plan Financial Year 2016/17. London: Sentencing Council.

Sentencing Guidelines Council (2004). Overarching Principles: Seriousness. London: Sentencing Guidelines Council.

- (2007). Reduction in sentence for a guilty plea: definitive guideline. London: Sentencing Guidelines Council.

- (2008). Magistrates' Court Sentencing Guidelines: definitive guideline. London: Sentencing Guidelines Council.

Shelton, J L, T Corey, W H Donaldson and E H Dennison (2011). 'Neonaticide: A Comprehensive Review of Investigative and Pathologic Aspects of 55 Cases'. In: Journal of Family Violence 26.4, pp. 263-276. DOI: 10.1007/s10896-011-9362-8.

Sherman, L W (2013). 'The rise of evidence-based policing: targeting, testing, and tracking'. In: Crime and Justice 42.1, pp. 377-451. DOI: 10.1086/670819.

Sherman, L W, M Bland, P House and H Strang (2016a). The Felonious Few vs. The Miscreant Many. Cambridge: Cambridge Centre for Evidence Based Policing. URL: http://www.anzsebp.com/images/docs/WA_Felonious_Few_Version_12_2.pdf.

Sherman, L W and J E Eck (2002). 'Policing for crime prevention'. In: Evidence-Based Crime Prevention. Ed. by L W Sherman, D P Farrington, B C Welsh and D L MacKenzie. London: Routledge. Chap. 8, pp. 295-329.

Sherman, L W, P Neyroud and E Neyroud (2016b). 'The Cambridge Crime Harm Index (CHI): measuring total harm from crime based on sentencing guidelines'. In: Policing 10.3, pp. 171-183. DOI: $10.1093 /$ police/paw003.

Wolfgang, M E, R M Figlio, P E Tracy and S I Singer (1985). The National Survey of Crime Severity. Washington, DC: US Department of Justice. 


\section{A Notifiable Offence List categories}

\begin{tabular}{|c|c|c|c|}
\hline NOL category ${ }^{a}$ & $\mathrm{CHI}^{\mathrm{b}}$ & $\mathrm{CSS}^{\mathrm{c}}$ & Count $^{\mathrm{d}}$ \\
\hline 1, 4.1, 4.2, 4.10: Murder, manslaughter, infanticide & 5,475 & 7,979 & 574 \\
\hline 2: Attempted murder & 3,285 & 4,663 & 683 \\
\hline 3A: Conspiracy to commit murder & 1,460 & 2,019 & 48 \\
\hline 3B: Threats to kill & 10 & 280 & 17,286 \\
\hline 4.3: Intentional destruction of a viable unborn child & 365 & 15 & 7 \\
\hline 4.4: Causing death by dangerous driving & 1,095 & 1,092 & 448 \\
\hline 4.6: Causing death by careless driving (drink or drugs) & 548 & 1,595 & 28 \\
\hline 4.7: Causing or allowing death of child or vulnerable person & 1,095 & 1,006 & 23 \\
\hline 4.8: Causing death by careless or inconsiderate driving & 3 & 112 & 132 \\
\hline $\begin{array}{l}\text { 4.9: Causing death by driving: unlicensed, disqualified or un- } \\
\text { insured }\end{array}$ & 3 & 136 & 11 \\
\hline 5D: Assault with intent to cause serious harm & 1,460 & 1,965 & 23,029 \\
\hline 5E: Endangering life & 1,825 & 1,326 & 1,346 \\
\hline 8L: Harassment & 10 & 39 & 155,444 \\
\hline 8M: Racially/religiously aggravated harassment & 42 & 40 & 1,788 \\
\hline $8 \mathrm{~N}$ : Assault with injury & 19 & 184 & 402,316 \\
\hline 8P: Racially/religiously aggravated assault with injury & 182 & 285 & 2,982 \\
\hline 8Q: Stalking & 42 & 51 & 4,155 \\
\hline 9A: Public fear alarm or distress & 5 & 10 & 134,682 \\
\hline $\begin{array}{l}\text { 9B: Racially/religiously aggravated public fear, alarm or dis- } \\
\text { tress }\end{array}$ & 42 & 24 & 29,173 \\
\hline 10A: Possession of firearms with intent & 1,825 & 635 & 1,522 \\
\hline 10B: Possession of firearms offences & 183 & 327 & 3,246 \\
\hline 10C: Possession of other weapons & 19 & 58 & 9,117 \\
\hline 10D: Possession of article with blade or point & 19 & 55 & 11,498 \\
\hline 11A: Cruelty to children/young persons & 84 & 146 & 12,942 \\
\hline 13: Child abduction & 273 & 293 & 1,039 \\
\hline 14: Procuring an illegal abortion & - & 1,020 & 7 \\
\hline 15: Concealing an infant death close to birth & 183 & 164 & 5 \\
\hline 17A: Sexual assault on a male aged 13 and over & 19 & 747 & 3,455 \\
\hline 17B: Sexual assault on a male child under 13 & 182 & 817 & 2,617 \\
\hline 19C: Rape of a female aged 16 and over & 1,825 & 2,895 & 22,524 \\
\hline 19D: Rape of a female child under 16 & 1,825 & 3,872 & 5,254 \\
\hline 19E: Rape of a female child under 13 & 2,920 & 3,229 & 4,181 \\
\hline 19F: Rape of a male aged 16 and over & 1,825 & 2,930 & 1,279 \\
\hline 19G: Rape of a male child under 16 & 1,825 & 3,905 & 669 \\
\hline 19H: Rape of a male child under 13 & 2,920 & 2,535 & 1,792 \\
\hline 20A: Sexual assault on a female aged 13 or over & 19 & 443 & 27,852 \\
\hline 20B: Sexual assault on a female child under 13 & 182 & 1,143 & 7,382 \\
\hline 21: Sexual activity involving a child under 13 & 730 & 753 & 5,884 \\
\hline 22A: Causing sexual activity without consent & 19 & 923 & 585 \\
\hline 22B: Sexual activity involving a child under 16 & 730 & 709 & 11,337 \\
\hline 23: Incest or familial sexual offences & 1,278 & 1,046 & 771 \\
\hline 24: Exploitation of prostitution & 10 & 370 & 173 \\
\hline 26: Bigamy & 14 & 164 & 72 \\
\hline
\end{tabular}




\begin{tabular}{|c|c|c|c|}
\hline NOL category ${ }^{a}$ & $\mathrm{CHI}^{\mathrm{b}}$ & $\mathrm{CSS}^{\mathrm{c}}$ & Count $^{\mathrm{d}}$ \\
\hline 27: Soliciting for the purpose of prostitution & 1 & 4 & 588 \\
\hline 28A/B/C/D: Burglary in a dwelling & 19 & 438 & 192,712 \\
\hline 29: Aggravated burglary in a dwelling & 365 & 2,127 & 1,700 \\
\hline 30A/B: Burglary in a building other than a dwelling & 10 & 117 & 206,419 \\
\hline 31: Aggravated burglary in a building other than a dwelling & 730 & 1,513 & 197 \\
\hline 33: Going equipped for stealing & 3 & 34 & 2,664 \\
\hline 33A: Making, supplying or possessing articles for use in fraud & 2 & 123 & 2,626 \\
\hline 34A: Robbery of business property & 365 & 746 & 5,428 \\
\hline 34B: Robbery of personal property & 365 & 746 & 45,679 \\
\hline 35: Blackmail & 365 & 803 & 5,895 \\
\hline 36: Kidnapping & 548 & 1,213 & 2,998 \\
\hline 37.1: Causing death by aggravated vehicle taking & 548 & 722 & 6 \\
\hline 37.2: Aggravated vehicle taking & 10 & 48 & 5,701 \\
\hline $\begin{array}{l}\text { 38: Profiting from/concealing knowledge of the proceeds of } \\
\text { crime }\end{array}$ & 5 & 242 & 1,590 \\
\hline 39: Theft from the person & 2 & 86 & 83,139 \\
\hline $\begin{array}{l}\text { 40: Theft in a dwelling other than from automatic ma- } \\
\text { chine/meter }\end{array}$ & 2 & 50 & 51,178 \\
\hline 41: Theft by an employee & 5 & 53 & 10,656 \\
\hline 42: Theft of mail & 2 & 85 & 2,358 \\
\hline 43: Dishonest use of electricity & 1 & 7 & 2,494 \\
\hline 44: Theft or unauthorised taking of pedal cycle & 2 & 16 & 86,520 \\
\hline 45: Theft from a vehicle & 2 & 34 & 238,850 \\
\hline 46: Shoplifting & 2 & 13 & 336,318 \\
\hline 47: Theft from an automatic machine or meter & 2 & 108 & 3,943 \\
\hline 48: Theft or unauthorised taking of motor vehicle & 5 & 124 & 76,179 \\
\hline 49: Other theft & 2 & 33 & 343,742 \\
\hline 49A: Making off without payment & 1 & 8 & 64,554 \\
\hline 51: Frauds by company director, sole trader etc & 182 & 733 & - \\
\hline 52: False accounting & 1 & 167 & - \\
\hline 53B: Preserved other fraud and repealed fraud offences & 91 & 208 & - \\
\hline $\begin{array}{l}\text { 53C: Fraud by false representation - cheque, plastic card and } \\
\text { online bank accounts }\end{array}$ & 10 & 86 & - \\
\hline 53D: Fraud by false representation - other fraud & 10 & 224 & - \\
\hline 53E: Fraud by failing to disclose information & 10 & 24 & - \\
\hline 53F: Fraud by abuse of position & 252 & 224 & - \\
\hline 53G: Obtaining services dishonestly & 10 & 123 & - \\
\hline 53H: Making or supplying articles for use in frauds & 2 & 123 & - \\
\hline 53J: Possession of articles for use in frauds & 2 & 123 & 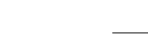 \\
\hline 54: Handling stolen goods & 2 & 54 & 5,295 \\
\hline 55: Bankrupcy offences & - & 47 & 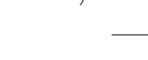 \\
\hline 56A: Arson endangering life & 730 & 837 & 3,273 \\
\hline 56B: Arson & 19 & 185 & 18,686 \\
\hline 58A: Criminal damage to a dwelling & 2 & 7 & 125,346 \\
\hline 58B: Criminal damage to a building other than a dwelling & 2 & 7 & 52,099 \\
\hline 58C: Criminal damage to a vehicle & 2 & 7 & 227,159 \\
\hline 58D: Other criminal damage & 2 & 7 & 110,822 \\
\hline
\end{tabular}




\begin{tabular}{|c|c|c|c|}
\hline NOL category ${ }^{a}$ & $\mathrm{CHI}^{\mathrm{b}}$ & $\mathrm{CSS}^{\mathrm{c}}$ & Count $^{\mathrm{d}}$ \\
\hline 58J: Racially/religiously aggravated criminal damage & 5 & 19 & 2,046 \\
\hline $\begin{array}{l}\text { 59: Threat/possession with intent to commit criminal dam- } \\
\text { age }\end{array}$ & 2 & 59 & 12,823 \\
\hline 60: Forgery or use of drug prescription & 3 & 55 & 394 \\
\hline 61: Other forgery & 3 & 155 & 2,841 \\
\hline 61A: Possession of false documents & 3 & 199 & 1,018 \\
\hline 62A: Violent disorder & 183 & 365 & 987 \\
\hline 66: Other offences against the state or public order & 5 & 78 & 39,422 \\
\hline 67: Perjury & 91 & 114 & 122 \\
\hline 69: Offender management act & 183 & 175 & 2,714 \\
\hline 70: Sexual activity etc. with a person with a mental disorder & 1,825 & 1,410 & 245 \\
\hline 71: Abuse of children through prostitution/pornography & 1,825 & 870 & 563 \\
\hline 72: Trafficking for sexual exploitation & 182 & 1,600 & 27 \\
\hline 73: Abuse of position of trust of a sexual nature & 10 & 243 & 239 \\
\hline 76: Aiding suicide & 1,095 & 4,392 & 35 \\
\hline 79: Perverting the course of justice & 42 & 165 & 6,376 \\
\hline 80: Absconding from lawful custody & 6 & 10 & 501 \\
\hline 81: Other firearms offences & 183 & 1,365 & 244 \\
\hline 83: Bail offences & 6 & 54 & 192 \\
\hline 86: Obscene publications etc & 91 & 155 & 12,883 \\
\hline 88A: Sexual grooming & 548 & 496 & 1,021 \\
\hline 88C: Other miscellaneous sexual offences & 730 & 1,001 & 232 \\
\hline 88D: Unnatural sexual offences & 183 & 53 & 35 \\
\hline 88E: Exposure and voyeurism & 10 & 41 & 8,154 \\
\hline 90: Other knives offences & - & 55 & - \\
\hline 92A: Trafficking in controlled drugs & 365 & 497 & 25,824 \\
\hline 92C: Other drug offences & 10 & 11 & 595 \\
\hline 92D: Possession of controlled drugs & 3 & 9 & 29,117 \\
\hline 92E: Possession of controlled drugs & 2 & 3 & 93,160 \\
\hline 95: Disclosure, obstruction, false or misleading statements & 2 & 16 & 230 \\
\hline 96: Wildlife offences & 4 & 175 & 83 \\
\hline 99: Other notifiable offences & - & 153 & - \\
\hline 104: Assault without injury on a constable & 2 & 9 & 15,454 \\
\hline 105A: Assault without injury & 1 & 16 & 343,212 \\
\hline 105B: Racially/religiously aggravated assault without injury & 10 & 36 & 5,585 \\
\hline 106: Modern slavery & 365 & 1,480 & 880 \\
\hline 126: Interfering with a motor vehicle & 3 & 12 & 45,558 \\
\hline 802: Dangerous driving & 10 & 120 & 4,077 \\
\hline 814: Fraud forgery associated with vehicle or driver records & 2 & 8 & 498 \\
\hline
\end{tabular}

${ }^{\mathrm{a}}$ Home Office (2011) ${ }^{\mathrm{b}}$ Eleanor Neyroud, personal communication

c Office for National Statistics 2016a) d Home Office 2017b) 